\title{
MARKETABLE SURPLUS GABAH DI KECAMATAN LEBONG SAKTI KABUPATEN LEBONG PROVINSI BENGKULU
}

\section{MARKETABLE SURPLUS OF PADDY IN LEBONG SAKTI DISTRICT OF LEBONG REGENCY BENGKULU PROVINCE}

\author{
Zuhriati, Satria Putra Utama, dan Reswita \\ Jurusan Sosial Ekonomi Pertanian Fakultas Pertanian \\ Universitas Bengkulu
}

\begin{abstract}
The objectives of this study are to identify the farmers' characteristics in marketable surplus of paddy context in Lebong Sakti District; to estimated the rate of marketable surplus of paddy in Lebong Sakti District; and to their with influenced factors of marketable surplus of paddy in Lebong Sakti District. The respondent so were byselected using simple random sampling with the total 70 farmers. Statistical analysis used in this study was multiple linear regression analysis with Ordinary Least Square. Based on the result of the study and discussion, in average the age of the farmers is 43.94 years old, the level of formal education was 9.16 year while 3.74 for non-formal times a year, experience in paddy farming was 14.94 years, the number of family member was 4 people, income from non paddy shell field farming was Rp 3,301,240.00 and the field area for paddy shell field farming was $0.86 \mathrm{Ha}$. The percentage of marketable surplus of paddy was $31.85 \%$ of total production. While for Non-real, the percentage of marketable surplus of paddy was $3.25 \%$ of total production in. Total production and ownership status factory had a positive influence toward marketable surplus of paddy while number of family member had a negative influence to marketable surplus of paddy.
\end{abstract}

Keywords: Marketable Surplus, Paddy

\section{PENDAHULUAN}

Di Kecamatan Lebong Sakti, kebiasaan petani ketika panen cenderung menjual hasil panen mereka. Kadang hasil panen langsung dijual di sawah dan sebagian juga ada yang menjual setelah padi sampai dirumah. Petani menjual hasil panen karena berbagai alasan seperti: jumlah panen yang relatif cukup banyak, untuk memenuhi berbagai kebutuhan keluarganya, untuk membayar hutang biaya usahatani padi, petani takut hasil panen padi mudah rusak 
karena terbatasnya tempat penjemuran selain itu juga karena petani tidak memiliki tempat penyimpanan padi sehingga petani menjual hasil panen setelah digunakan untuk berbagai alokasi produksi. Dengan melihat kebiasaan petani padi di Kecamatan Lebong Sakti ini ketika panen sebelum menjual hasil produksi selalu mengaokasikan poroduksi untuk berbagai keperluan dan sisanya kemudian dijual maka peneliti tertarik untuk meneliti seberapa besar marketable surplus gabah serta faktor yang mempengaruhi besarnya marketable surplus gabah di Kecamatan Lebong Sakti.

\section{METODE PENELITIAN}

Penelitian dilaksanakan di Kecamatan Lebong Sakti Kabupaten Lebong Kabupaten Lebong Propinsi Bengkulu, Pemilihan lokasi penelitian dilakukan secara purposive (sengaja) dengan pertimbangan bahwa di Kecamatan Lebong Sakti hampir seluruh penduduknya melakukan usahatani padi sawah. Penelitian ini dilakukan dari bulan Desember sampai Januari tahun 2014. Data yang dikumpulkan dalam penelitian ini adalah meliputi data primer dan data sekunder. Data primer diperoleh melalui observasi dan melalui wawancara langsung dengan responden menggunakan daftar pertanyaan (kuesioner) yang telah dipersiapkan terlebih dahulu. Penentuan responden untuk petani dilakukan dengan teknik Simple random sampling dengan jumlah responden sebanyak 70 petani. Sedangkan data sekunder diperoleh dari literature-literatur atau pustaka dan instansi-instansi atau lembaga-lembaga yang terkait dalam penelitian ini, serta menggunakan referensi penelitian terdahulu.

Dalam menganalisis karakteristik sosial ekonomi petani dalam konteks marketable surplus Gabah Di Kecamatan lebong Sakti digunakan data primer di tingkat rumah tangga petani responden. Kemudian Data dan informasi yang telah diperoleh dinalisis secara deskriptif. Untuk analisis Marketable Surplus Gabah Menurut Strauss (1984) dalam Listaria (2008) dinyatakan sebagai selisih antara jumlah produk yang dihasilkan dengan jumlah produk yang dialokasikan untuk berbagai keperluan. Secara matematis Marketable surplus atau MS dinyatakan sebagai berikut:

$$
M S=Y-\left(X_{1}+X_{2}+X_{3}+X_{4}+X_{5}\right)
$$

dimana MS adalah Marketable surplus (Kg/Ut/MT), Y adalah Total Produksi $(\mathrm{Kg} / \mathrm{Ut} / \mathrm{MT}), \mathrm{X}_{1}$ adalah Penggunaan Bibit $(\mathrm{Kg} / \mathrm{Ut} / \mathrm{MT}), \mathrm{X}_{2}$ adalah Upah Panen $(\mathrm{Kg} / \mathrm{Ut} / \mathrm{MT}), X_{3}$ adalah Sewa Lahan $(\mathrm{Kg} / \mathrm{Ut} / \mathrm{MT}), X_{4}$ adalah Biaya Pupuk (Kg/Ut/MT), dan $X_{5}$ adalah Konsumsi (Kg/Ut/MT).

Analisis faktor-faktor yang mempengaruhi Marketable surplus gabah digunakan persamaan linear berganda dengan metode kuadrat terkecil (Ordinary Least Square) yang di rumuskan sebagai berikut: 


\section{$M S=a_{0}+b_{1} Y_{1}+X_{2}+X_{3}+X_{4}+a_{1} D_{1}+e$}

dimana: MS adalah Marketable Surplus (Kg/Ut/MT), $\mathrm{Y}_{1}$ adalah Total Produksi $(\mathrm{Kg} / \mathrm{Ut} / \mathrm{MT}), X_{2}$ adalah Harga Gabah $(\mathrm{Rp} / \mathrm{Kg}), X_{3}$ adalah Jumlah Tanggungan Keluarga (Orang), $X_{4}$ adalah Jumlah Penerimaan di Luar Usahatani Padi (Rp/Ut/MT), a adalah Konstanta, $\mathrm{a}_{1}, \mathrm{~b}_{1}$ adalah Koefisien regresi, $\mathrm{D}_{1}$ adalah Status Kepemilikan Lahan dimana $\mathrm{D}_{1}$ sama dengan 1 , jika Milik Sendiri dan $\mathrm{D}_{0}$ sama dengan 0 jika Non Pemilik, serta e adalah variabel pengganggu.

\section{HASIL DAN PEMBAHASAN}

\section{Karateristik Petani Dalam Konteks Marketable surplus Gabah}

Dari hasil Penelitian diketahui rata-rata umur petani di Kecamatan Lebong Sakti adalah 43,94 tahun. Persentase terbesar dari umur petani padi di daerah penelitian berada pada kelompok umur(22-42 tahun) yaitu sebesar $52,86 \%$. Berdasarkan rata-rata umur petani sebahagian besar petani masih berada pada usia produktif. Usia produktif berhubungan dengan kemampuan kerja petani yaitu mempunyai kemampuan kerja lebih besar dibandingkan dengan anggota usia non produktif. Menurut Mubyarto (1987) bahwa umur 15 sampai 64 tahun merupakan golongan usia produktif.

Dalam konteks marketable surplus ini jika petani tergolong dalam usia produktif maka akan lebih semangat dalam berusahatani guna untuk mencapai hasil produksi yang maksimal. Seiring dengan tingginya produksi yang dihasilkan akan berpengaruh terhadap marketable surplus gabah. Maksudnya jika produksi tinggi maka petani tersebut memiliki kesempatan yang banyak untuk dapat memasarkan hasil produksinya meskipun telah di kurangi sebelumnya untuk berbagai alokasi produk.

Hasil penelitian menunjukkan bahwa rata-rata pendidikan formal petani di Kecamatan Lebong Sakti adalah 9,16 tahun dengan kisaran 1 tahun sampai 19 tahun sedangkan pendidikan non formal petani di Kecamatan Lebong Sakti rata-rata adalah 3,74 kali setahun. Hasil penelitian menunjukkan kisaran pengalaman dalam berusahatani padi antara 1 sampai 48 tahun dengan ratarata 14,94 tahun. Bila dikaitkan ke dalam konteks marketable surplus, pengalaman usahatani ini akan memberikan pengaruh. Hal ini disebabkan karena dengan semakin berpengalaman seorang petani dalam melakukan usahataninya maka petani tersebut akan paham akan berbagai resiko dalam memaksimalkan produksi yang diperolehnya, semakin lama pengalaman usahatani seseorang akan dapat meningkatkan jumlah produksi. Seiring dengan meningkatnya produksi akan berdampak juga terhadap besar kecilnya marketable surplus. 
Dalam konteks marketable surplus, jumlah tanggungan keluarga ini memberikan pengaruh terhadap besar kecilnya marketable surplus gabah. Semakin banyak jumlah tanggungan keluarga akan menyebabkan semakin berkurangnya jumlah produksi yang dipasarkan.

Dalam konteks marketable surplus, penerimaan luar usahatani ini tidak menunjukkan hubungan yang nyata terhadap marketable surplus. Sehingga besar kecilnya penerimaan luar usahatani tidak mempengaruhi besar kecilnya marketable surplus. Akan tetapi secara statistik dengan menggunakan uji parsial memberikan pengaruh yang negatif, artinya jika penerimaan luar usahatani tinggi maka marketable surplus akan berkurang. Hal ini sesuai dengan studi di Cina dalam Ilham dkk (2010) penerimaan luar usahatani berpengaruh negatif terhadap MS dan memberikan berpengaruh positif pada konsumsi biji-bijian. dalam konteks marketable surplus petani yang status lahannya merupakan lahan milik sendiri akan memperbesar marketable surplus. Hal ini disebabkan karena petani tersebut tidak harus membayar sewa lahan lagi dari alokasi produksi akan tetapi apabila petani tersebut tidak memiliki lahan garapan maka akan memperkecil marketable surplus.

\section{Analisis Marketable Surplus Gabah}

\section{Produksi dan Alokasi Penggunaan}

Alokasi yang dilakukan petani pada kegiatan usahataninya dibedakan menjadi dua, yaitu alokasi atau pengeluaran secara riil dan non riil. Alokasi secara riil adalah alokasi atau pengeluaran yang benar-benar dikeluarkan petani secara langsung. Sedangkan alokasi atau pengeluaran secara non riil adalah alokasi atau pengeluaran yang semestinya dikeluarkan oleh petani baik itu secara langsung maupun secara tidak langsung. Hasil penghitungan marketable surplus baik secara riil dan non riil disajikan pada Tabel 1.

Tabel 1. Produksi rata-rata dan alokasinya

\begin{tabular}{|c|c|c|c|c|c|c|c|c|}
\hline \multicolumn{5}{|c|}{ Alokasi Secara Riil (Kg/MT) } & \multicolumn{4}{|c|}{$\begin{array}{c}\text { Alokasi Secara Non Riil } \\
(\mathrm{Kg} / \mathrm{MT})\end{array}$} \\
\hline Uraian & UT & $(\%)$ & $\mathrm{Ha}$ & $(\%)$ & UT & $(\%)$ & $\mathrm{Ha}$ & $(\%)$ \\
\hline Produksi & 3636.34 & 100.00 & 4341.03 & 100.00 & 3636.34 & 100.00 & 4341.03 & 100.00 \\
\hline Penggunaan bibit & 28.74 & 0.79 & 37.15 & 0.86 & 28.74 & 0.79 & 37.15 & 0.86 \\
\hline Upah Panen & 606.06 & 16.67 & 723.50 & 16.67 & 606.06 & 16.67 & 723.50 & 16.67 \\
\hline Sewa Lahan & 27.43 & 0.75 & 44.80 & 1.03 & 1184.69 & 32.58 & 1377.54 & 31.73 \\
\hline $\begin{array}{l}\text { Pembayaran } \\
\text { Pupuk }\end{array}$ & 168.69 & 4.64 & 234.06 & 5.39 & 168.69 & 4.64 & 234.06 & 5.39 \\
\hline Konsumsi & 1647.09 & 45.30 & 1988.3 & 45.80 & 1647.09 & 45.30 & 1915.22 & 45.80 \\
\hline $\begin{array}{l}\text { Marketable } \\
\text { surplus }\end{array}$ & 1158.34 & 31.85 & 1313.34 & 30.25 & 118 & 3.25 & 137.20 & 3.1 \\
\hline
\end{tabular}

Sumber: Data Primer diolah, Januari 2014

190 | Zuhriati, Satria Putra Utama, dan Reswita, Marketable Surplus Gabah ... 
Tabel 1 menginformasikan bahwa rata-rata produksi padi yang diperoleh petani di Kecamatan Lebong Sakti pada musim tanam Maret 2013 adalah sebesar 3.636,34 kg/MT gabah. Rata-rata total produksi sebesar 3.636,34 $\mathrm{Kg} / \mathrm{MT}$ dengan rata-rata luas lahan sebesar 0,86 Ha sehingga rata-rata total produksi sebesar $4341.03 \mathrm{Kg} / \mathrm{Ha}$.

Dari uraian di atas diketahui dari rata-rata total produksi sebesar 3.636,34 $\mathrm{kg} / \mathrm{MT}$. Persentase alokasi produk yang paling besar digunakan adalah untuk kebutuhan konsumsi yaitu sebesar 45,30\%. Persentase ini lebih tinggi bila dibandingkan dengan alokasi produk lainnya seperti alokasi untuk biaya panen $16,67 \%$ dan pembayaran pupuk 4,64\%. Apabila dilihat alokasi per Ha juga persentase alokasi produksi yang dikeluarkan juga untuk persentase paling besar untuk konsumsi sebesar 45,80\%. Hal ini disebabkan karena musim tanam hanya dilakukan sekali dalam setahun, dan alasan inilah yang membuat petani lebih banyak mengalokasikan produksi nya untuk keperluan konsumsi rumah tangga nya sampai musim panen tahun berikutnya. Semakin banyak jumlah tanggungan keluarga maka semakin banyak pula jumlah produksi yang dialokasikan untuk kebutuhan konsumsi.

Berdasarkan hasil pada Tabel 1 diketahui bahwa dari rata-rata total produksi sebesar 3.636,34 kg/MT dialokasikan untuk keperluan bibit musim tanam berikutnya sebesar $0,79 \%$ secara riil maupun non riil. Persentase penggunaan bibit secara riil ini besarnya sama dengan alokasi secara non riil. Hal ini dikarenakan petani dilokasi penelitian selalu mengalokasikan produksi yang diperolehnya ketika panen untuk kebutuhan bibit pada musim tanam berikutnya.

Sedangkan alokasi untuk sewa lahan secara riil sebesar $0,75 \%$ dari ratarata total produksi dan 32,58\% untuk sewa lahan secara non riil. Perbedaan persentase sewa lahan antara riil dan non riil ini dikarenakan petani di Kecamatan Lebong Sakti hampir sebahagian besar memiliki lahan garapan sendiri yaitu sebanyak $97,14 \%$ bila dibandingakan dengan petani yang menyewa lahan hanya sebesar $2,28 \%$, sehingga petani yang memiliki lahan sendiri mereka tidak perlu mengeluarkan sewa lahan bila dibandingkan dengan petani yang menyewa lahan. Di Kecamatan Lebong Sakti untuk sewa lahan berlaku sistem bagi hasil antara pemilik dan penggarap. Sistem yang diterapkan adalah sistem 3:1 yang artinya setiap petani panen maka petani tersebut berkewajiban mengeluarkan 1 karung gabah di setiap memperoleh 3 karung atau setara dengan $48 \mathrm{~kg}$ gabah.

Dari penelitian ini didapatkan bahwa jumlah petani yang mengalokasikan hasil panennya untuk pembayaran pupuk urea dan TSP sebanyak $4,64 \%$ secara riil maupun non riil. Petani terpaksa mengeluarkan produksi untuk pembayaran pupuk dikarenakan petani ke kurangan modal sehingga keadaan ini dimanfaatkan oleh para tengkulak dengan memberikan pinjaman pupuk. Pupuk tersebut nantinya dibayar ketika panen tiba dengan 
kesepakatan dibayar dalam bentuk natura. Tentu saja keadaan ini merugikan petani dengan alasan mereka harus membayar $50 \mathrm{~kg}$ pupuk dengan $48 \mathrm{~kg}$ gabah sementara harga gabah per $\mathrm{kg}$ nya lebih mahal bila dibandingkan dengan harga pupuk per $\mathrm{kg}$, namun petani tidak bisa berbuat banyak hanya saja pasrah dengan keadaan.

Salah satu kebiasaan masyarakat di Kecamatan Lebong Sakti ketika musim panen tiba adalah untuk upah atau biaya panen, biaya pupuk tidak dikeluarkan dalam bentuk uang tunai melainkan dibayar dalam bentuk natura. Tentu saja hal inilah yang akan memperkecil marketable surplus gabah. Ketika panen padi berlaku sistem borongan. Sistem borongan ini meliputi anak-anak, remaja dan orang dewasa tidak menutup kemungkinan orang tua. Kebiasaan ini telah ada sebelumya dan masih diterapkan sampai saat ini dengan alasan panen padi dapat selesai dalam satu hari, dan menghemat waktu. Sistem borongan yang berlaku pada daerah penelitian ini dengan ketentuan 6:1. Artinya dalam produksi 6 karung gabah petani menyisihkan 1 karung gabah untuk upah panen.

Setelah petani mengalokasikan hasil produksi untuk berbagai keperluan seperti penggunaan bibit, biaya panen, sewa lahan, pembayaran pupuk serta untuk kebutuhan konsumsi dimana semuanya itu di keluarkan dalam bentuk natura, maka sisa produksi setelah dikurangi dengan berbagai keperluan langsung dapat dijual ke pasar. Istilah ini lebih dikenal dengan marketable surplus. Berdasarkan hasil pada Tabel 1 diketahui bahwa total produksi ratarata sebesar $3.636,34 \mathrm{~kg}$ pada musim tanam Maret 2013. Dan besarnya marketable surplus sebesar $81.048 \mathrm{~kg} / \mathrm{Ut}$ dengan rata-rata $1.158,34 \mathrm{~kg} / \mathrm{Ut}$.

Diketahui besarnya marketable surplus gabah di Kecamatan Lebong Sakti pada musim tanam Maret 2013 secara riil adalah sebesar 31,85\% dan sisa nya sebesar $68,15 \%$ digunakan untuk berbagai alokasi produksi seperti yang telah dijelaskan pada uraian sebelumnya, sedangkan besarnya marketable surplus secara non riil adalah 3,25\%. Angka ini lebih kecil bila dibandingkan dengan marketable surplus secara riil. Hal ini disebabkan petani di lokasi penelitian hampir semuanya mengalokasikan atau mengeluarkan produksi yang diperoleh ketika panen untuk keperluan yang sama yaitu untuk kebutuhan rumah tangga dan kebutuhan usahataninya. Semakin banyak alokasi produksi yang dilakukan petani maka akan menyebabkan marketable surplus semakin kecil dan sebaliknya.

Berdasarkan hasil pada Tabel 1 diketahui bahwa persentase besarnya marketable surplus gabah di Kecamatan Lebong Sakti pada musim tanam Maret 2013 sebesar 3.25\%. (Secara non riil) dan untuk riil besarnya marketable surplus jika dilihat dari $\mathrm{Kg} / \mathrm{Ut}$ adalah 31,85\% sedangkan jika dilihat dari sisi $\mathrm{Kg} / \mathrm{Ha}$ nya sebesar $30.25 \%$ lebih kecil bila dibandingkan dengan alokasi produksi terutama alokasi untuk keperluan konsumsi sebesar 45,30\%. Hal ini disebabkan karena petani lebih mengutamakan produksi yang diperolehnya untuk 
kebutuhan konsumsi keluarga daripada menjualnya langsung kepasar dengan alasan musim tanam hanya dilakukan satu kali dalam setahun.

Tabel 1 menginformasikan bahwa besarnya marketable surplus gabah di Kecamatan Lebong Sakti pada musim tanam Maret 2013 adalah sebesar 31,85\% (Kg/Ut/MT). Sedangkan besarnya persentase marketable surplus sebesar 30,25\% $(\mathrm{Kg} / \mathrm{Ha} / \mathrm{MT})$. Angka ini jauh lebih kecil bila dibandingkan dengan penelitian yang dilakukan oleh Ilham dkk (2010) mengenai marketable surplus gabah, Dimana besarnya marketable surplus gabah pada agroekosistem sawah di Jawa sebesar $81.85 \%(\mathrm{Kg} / \mathrm{Ha} / \mathrm{MT})$.

\section{Faktor-faktor yang Mempengaruhi Marketable Surplus Gabah}

Marketable surplus adalah jumlah produksi yang dapat dipasarkan oleh petani setelah dikurangi untuk berbagai alokasi produksi dalam bentuk natura. Untuk melihat faktor-faktor yang mempengaruhi marketable surplus gabah di Kecamatan Lebong Sakti digunakan model regresi linear berganda.

Data yang digunakan dalam analis regresi linear berganda ini adalah data alokasi atau pengeluaran secara riil yang dilakukan oleh petani. Adapun hasil estimasi model regresi linear berganda pada analisis marketable surplus gabah di Kecamatan Lebong Sakti pada musim tanam bulan Maret 2013 dapat dilihat pada Tabel 2.

Tabel 2. Hasil estimasi model marketable surplus gabah di Kecamatan Lebong Sakti Kabupaten Lebong Provinsi Bengkulu Tahun 2013

\begin{tabular}{|c|c|c|c|c|}
\hline No & Variabel Bebas & $\begin{array}{c}\text { Koefisien } \\
\text { Regresi }\end{array}$ & Std Error & $\mathrm{T}_{\text {hitung }}$ \\
\hline 1 & Total Produksi (X1) & 0.43967 & 0.02651 & $16.58^{*}$ \\
\hline 2 & Harga Gabah ( X2) & -0.27203 & 0.1383 & -1.967 \\
\hline 3 & Jumlah Tanggungan Keluarga ( X3 ) & -58.522 & 25.76 & -2.272 * \\
\hline 4 & Penerimaan Luar Usahatani Padi ( X4) & -0.000015883 & 0.00003774 & -0.4208 \\
\hline \multirow[t]{6}{*}{5} & Status Kepemilikan Lahan ( D1 ) & 763.84 & 289.2 & 2.64 * \\
\hline & Konstanta & 76.231 & & \\
\hline & $\mathrm{R}^{2}$ & 0.8503 & & \\
\hline & $F_{\text {hitung }}$ & 72.684 & & \\
\hline & $\mathrm{T}_{\text {tabel }}$ & 1.994 & & \\
\hline & $F_{\text {tabel }}$ & 2.35 & & \\
\hline
\end{tabular}

Sumber : Data Primer diolah, Januari 2014

Keterangan $:\left(^{*}\right)=$ Signifikan pada tingkat kepercayaan $95 \%(\alpha / 2=0,025)$ dengan nilai $t$ tabel $+/-1.994$

Tabel 2 menginformasikan bahwa besarnya $\mathrm{R}^{2}$ atau Koefisien determinasi dari hasil estimasi pada analisis marketable surplus gabah di Kecamatan Lebong Sakti adalah sebesar $0.85 \%$ berarti bahwa variabel total produksi, harga gabah, jumlah tanggungan keluarga, penerimaan luar usahatani dan status 
kepemilikan lahan mempengaruhi besarnya yang dapat dipasarkan setelah dialokasikan yang di kenal dengan istilah marketable surplus. Sedangkan sisanya, yaitu $15 \%$, dijelaskan oleh variabel-variabel lain yang tidak dimasukkan dalam estimasi ini dan diduga seperti variabel luas lahan, pendapatan petani padi serta harga barang lain.

Dari hasil estimasi diatas dapat diketahui bahwa nilai $F_{\text {hitung }}(72.684)$ dan nilai $F_{\text {tabel }}(2.35)$ artinya nilai $F_{\text {hitung }}$ lebih besar daripada nilai $F_{\text {tabel. }}$. Dengan demikian dapat disimpulkan bahwa variabel bebas secara bersama-sama memberikan pengaruh yang nyata terhadap variabel tak bebas. Sedangkan untuk menguji pengaruh masing- masing variabel bebas terhadap variabel tak bebas digunakan uji-t. Hasil uji-t diperoleh bahwa variabel total produksi dan status kepemilikan lahan memberikan pengaruh yang nyata positif terhadap besarnya marketable surplus, variabel jumlah tanggungan keluarga memberikan pengaruh yang nyata negatif, sedangkan variabel penerimaan luar usahatani dan harga gabah tidak berpengaruh nyata.

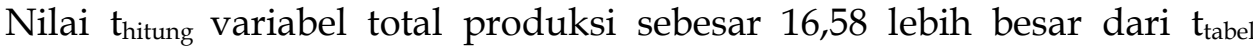
$(1,994)$, artinya hipotesis alternatef $(\mathrm{Ha})$ diterima. Dengan demikian, total produksi berpengaruh nyata dan memberikan pengaruh yang positif terhadap marketable surplus. Artinya, semakin banyak jumlah produksi yang diterima petani ketika musim panen maka semakin banyak pula jumlah padi yang dapat dipasarkan petani setelah dikurangi untuk berbagai keperluan. Hasil yang sama juga terlihat pada penelitian yang dilakukan sebelumnya oleh Nusril dkk (2007) mengatakan bahwa variabel total produksi memberikan pengaruh yang nyata positif terhadap besarnya marketable surplus beras.

Variable harga gabah tidak berpengaruh nyata terhadap marketable surplus dan memiliki tanda negatif. Temuan ini berlawanan dengan hasil penelitian terdahulu dimana harga beras berhubungan nyata dan memberikan pengaruh yang positif terhadap marketable surplus beras (Nusril dkk. ,2007). Pada penelitian yang dilakukan di Kecamatan Lebong Sakti ini, harga yang berlaku di pasar bervariasi, sehingga meskipun harga gabah dipasar tinggi ketika mereka panen namun para petani tidak menjual hasil panennya dalam jumlah besar meskipun harga melambung tinggi dan konsumsi rumah tangga bersifat tetap atau konstan. Alasan petani dilokasi penelitian tidak menjual hasil panen ketika harga tinggi adalah mereka lebih memilih untuk menyimpan gabah tersebut dan kemudian menjualnya dalam bentuk beras.

Sedangkan untuk nilai $t_{\text {hitung }}$ sebesar $(-2,272)$ lebih kecil dari nilai $t_{\text {tabel }}(-$ $1,994)$ pada tingkat keyakinan $95 \%(\alpha / 2=0,05)$, Sehingga hipotesi alternatif $(\mathrm{Ha})$ diterima dan hipotesis nihil (Ho) ditolak. Dengan demikian jumlah tanggungan keluarga berhubungan nyata dengan marketable surplus dan memberikan pengaruh yang negatif terhadap besarnya marketable surplus gabah. Jumlah tanggungan keluarga pada penelitian ini berhubungan nyata terhadap besarnya marketable surplus. Meskipun variabel jumlah tanggungan keluarga 
berhubungan nyata akan tetapi memberikan pengaruh yang negatif. Artinya jumlah tanggungan keluarga ini akan mengurangi jumlah produksi yang dapat dipasarkan.Semakin banyak jumlaha tanggungan keluarga dalam sebuah rumah tangga maka kepala keluarga tersebut akan lebih banyak menyimpan atau mengalokasikan hasil panen nya untuk kebutuhan konsumsi keluarganya dibandingan menjual produksi kepasar meskipun harga jual gabah tinggi. Hal ini sesuai dengan penelitian sebelumnya yang dilakukan oleh Rosmawati (2009) tentang marketable surplus beras yang menyatakan bahwa yang memberikan pengaruh negatif terhadap marketable surplus adalah jumlah tanggungan keluarga.

Nilai $t_{\text {hitung }}$ pada variabel penerimaan luar usahatani sebesar $(-0,4208)$ lebih besar daripada nilai (-1.994). Dengan demikian hipotesis nihil (Ho) diterima dan hipotesis alternative (Ha) ditolak sehingga variabel penerimaan luar usahatani tidak berhubungan nyata dengan marketable surplus. Nnilai koefisien regresi menunjukkan bahwa penerimaan luar usahatani memberikan pengaruh negatif atau mengurangi jumlah produksi yang dipasarkan.

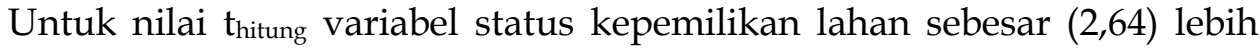
besar dari nilai tabel $(1,994)$. Hipotesis alternatif $(\mathrm{Ha})$ terbukti dan dapat diterima, sebaliknya hipotesis nihil (Ho) ditolak. Dengan demikian status kepemilikan lahan memberikan pengaruh nyata dan positif terhadap besarnya marketable surplus gabah. Hal ini sesuai dengan harapan bahwa di lokasi penelitian yang dilakukan di Kecamatan Lebong Sakti para petani hampir semuanya memiliki lahan garapan sendiri meskipun masih ada sedikit petani yang masih menyewa lahan untuk kegiatan usahatani.

\section{SIMPULAN DAN SARAN}

\section{Simpulan}

Berdasarkan hasil penelitian dan pembahasan yang telah dilakukan pada usahatani padi di Kecamatan Lebong Sakti pada musim tanam Maret 2013 dapat diambil kesimpulan sebagai berikut :

1. Berdasarkan hasil penelitian dan pembahasan, rata-rata umur petani adalah 43,94 tahun, tingkat pendidikan formal adalah 9,16, pendidikan non formal 3,74 kali per tahun, pengalaman berusahatani padi 14,94 tahun, jumlah tanggungan keluarga sebanyak 3,56 orang dan untuk penerimaan luar usahatani padi sebesar $\mathrm{Rp}$ 3.301.240. Serta rata-rata luas lahan yang digunakan untuk usahatani padi adalah $0,86 \mathrm{Ha}$.

2. Persentase marketable surplus gabah adalah sebesar $31,85 \%(\mathrm{Kg} / \mathrm{Mt})$ dari hasil produksi (riil). Sedangkan secara non riil Persentase marketable surplus gabah adalah sebesar 3,25\% (Kg/Mt) dari hasil produksi. Hasil ini diperoleh setelah total produksi yang dihasilkan oleh petani telah dialokasikan untuk berbagai keperluan termasuk untuk penggunaan bibit 
musim tanam berikutnya, biaya panen, sewa lahan, pembayaran pupuk dan untuk di konsumsi.

3. Faktor total produksi dan status kepemilikan lahan memiliki pengaruh yang nyata positif terhadap marketable surplus gabah sedangkan jumlah tanggungan keluarga memiliki pengaruh yang nyata negatif terhadap marketable surplus gabah. Sementara faktor penerimaan luar usahatani dan harga gabah tidak berpengaruh nyata dengan marketable surplus gabah.

\section{Saran}

1. Untuk meningkatkan marketable surplus gabah di Kecamatan Lebong Sakti, terlebih dahulu meningkatkan produksi. Dalam upaya meningkatkan produksi diperlukan perlu ada penyuluhan, pelatihan-pelatihan, serta tersedianya sarana dan prasarana yang dapat menunjang kegiatan usahatani sehingga produksi yang dihasilkan tinggi. Semakin tinggi produksi akan memperbesar marketable surplus.

2. Selain meningkatkan produksi, marketable surplus juga dapat ditingkatkan melalui memperkecil alokasi produksi. Sehingga produksi yang tinggi dan di ikuti dengan semakin sedikitnya alokasi produksi yang dilakukan petani akan dapat memperbesar marketable surplus gabah itu sendiri.

CATATAN: Artikel ini bagian dari Skripsi Zuhriati dengan judul yang sama

\section{DAFTAR PUSTAKA}

Ilham, Nyak, Nunung Kusnadi, Supena Friyatno, dan Erma Suryani. 2010. Faktor-faktor yang Menentukan Marketable Surplus Gabah. Pusat Analisis Sosial Ekonomi dan Kebijakan Pertanian Fakultas Ekonomi dan Manajemen Institut Pertanian Bogor. Jurnal Informatika Pertanian. 19(2): 45-75.

Listaria, Riza. 2008. Analisis Marketable surplus dan Faktor-faktor yang Mempengaruhi Marked Suply Serta Ketersediaan Beras di Kota Bengkulu. Skripsi. Universitas Bengkulu. Bengkulu. Tidak Dipublikasikan.

Mubyarto. 1987. Pengantar Ekonomi Pertanian. LP3ES. Jakarta

Nusril, H.S. Harahap, dan K. Sukiyono. 2007. Analisa Marketable surplus Beras (Studi Kasus di Desa Dusun Muara Aman Kecamatan Lebong Utara Kabupaten Lebong). Jurnal Akta Agrosia. 10(1): 32-39.

Rosmawati, Henny. 2009. Analisis Surplus dan Distribusi Pemasaran Beras Produksi Petani Kecamatan Buay Madang Kabupaten OKU Timur. FP Universitas Baturaja. Jurnal Agronobis. 1(1): 99-116. 